\title{
ANALISIS STRUKTUR TARIF PAJAK DALAM MELIHAT KEPATUHAN WAJIB PAJAK BADAN \\ (Studi Kasus pada PT. Bank Pembangunan Daerah Sulawesi Tenggara)
}

\author{
Mulyati Akib1 \\ ${ }^{1}$ Dosen Universitas Halu Oleo Kendari
}

\begin{abstract}
This study aims to determine and analyze the structure of tax rates to see taxpayer compliance which is PT. Bank Pembangunan Daerah of Southeast Sulawesi. Data collection methods used in this study are interviews, documentation and library studies. This study is descriptive analysis research. The results of this study indicate that companies that become taxpayers must have proof of registration as a taxpayer in the form of a Taxpayer Identification Number. PT. Bank Pembangunan Daerah of Southeast Sulawesi has registered as a taxpayer and had a Taxpayer Identification Number. The imposition of corporate tax rates is based on the gross circulation of the entity. PT. Bank Pembangunan Daerah of Southeast Sulawesi is subject to 25\% PPh tariff since its gross circulation value exceeds Rp. 4,800,000,000. PT. Bank Pembangunan Daerah Southeast Sulawesi also reports and pays the tax liability on time and precisely the amount in accordance with the tax rates and the time stated in the SPT.
\end{abstract}

Keywords: Tax Rates, Corporate Taxpayer, Compliance

\begin{abstract}
ABSTRAK
Penelitian ini bertujuan untuk mengetahui dan menganalisis struktur tarif pajak dalam melihat kepatuhan wajib pajak badan yaitu PT. Bank Pembangunan Daerah Sulawesi Tenggara. Metode pengumpulan data dalam penelitian ini adalah wawancara, dokumentasi dan studi kepustakaan. Penelitian ini merupakan penelitian analisis deskriptif. Hasil penelitian ini menunjukkan bahwa perusahaan yang menjadi wajib pajak harus memiliki bukti pendaftaran sebagai wajib pajak dalam bentuk Nomor Pokok Wajib Pajak (NPWP). PT. Bank Pembangunan Daerah Sulawesi Tenggara telah melakukan pendaftaran sebagai wajib pajak dan memiliki Nomor Pokok Wajib Pajak (NPWP). Pembebanan tarif pajak perusahaan didasarkan pada peredaran bruto entitas tersebut. PT. Bank Pembangunan Daerah Sulawesi Tenggara dikenakan tarif $\mathrm{PPh} 25 \%$ karena nilai peredaran brutonya melebihi Rp. 4.800.000.000. PT. Bank Pembangunan Daerah Sulawesi Tenggara juga melaporkan dan membayarkan kewajiban pajak tepat waktu dan tepat jumlah sesuai dengan tarif pajak dan waktu yang tertera dalam SPT.
\end{abstract}

Kata kunci: Tarif Pajak, Wajib Pajak Badan, Kepatuhan

Jurnal Akun Nabelo: Jurnal Akuntansi Netral, Akuntabel, Objektif Volume 1/Nomor 2/Jan 2019 Jurusan Akuntansi FE-Universitas Tadulako

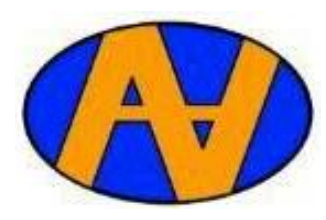




\section{A. PENDAHULUAN}

Pajak memiliki beberapa fungsi salah satunya fungsi anggaran di mana pajak dijadikan sebagai sumber dana bagi pemerintah untuk membiayai pengeluaranpengeluaran. Kontribusi pajak dalam Anggaran Pendapatan dan Belanja Negara (APBN) tiap tahun semakin meningkat. Hal ini menunjukkan bahwa peranan pajak semakin besar dalam APBN. Oleh karena itu, pemerintah harus terus berupaya untuk meningkatkan dan memperbaiki penerimaan pajak. Perbaikan sistem perpajakan berupa penyempurnaan kebijakan dan sistem administrasi perpajakan diharapkan dapat mengoptimalkan potensi perpajakan yang tersedia dengan menjunjung asas keadilan sosial. Salah satu upaya perbaikan sistem perpajakan di Indonesia adalah dengan disahkannya Undang-Undang Nomor 36 Tahun 2008 yang merupakan perubahan keempat dari Undang-Undang Nomor 7 Tahun 1983 tentang Pajak Penghasilan. Undang- Undang Nomor 36 Tahun 2008 ini disahkan pada tanggal 23 September 2008 dan mulai berlaku tanggal 1 Januari 2009.

Undang-Undang Nomor 36 Tahun 2008 tentunya akan menimbulkan reaksi yang beragam dari masyarakat, terutama yang terdaftar sebagai Wajib Pajak, baik Wajib Pajak Orang Pribadi (WPOP) maupun Wajib Pajak Badan (WPBadan). Salah satu bentuk reaksi masyarakat dapat dilihat dari perilaku kepatuhan pajak. Perilaku kepatuhan pajak menjadi sesuatu yang sangat penting karena pada saat yang bersamaan akan timbul upaya penghindaran pajak (tax evasion) yang berdampak pada besarnya penerimaan negara dari pajak.

Pajak dijadikan sebagai sumber penerimaan utama bagi pembiayaan negara dalam dekade terakhir ini. Kantor Pelayanan Pajak (KPP) Pratama Kendari sebagai salah satu unit kerja yang diberi wewenang memungut tagihan pajak bagi wajib pajak merilis sebuah data terkait realisasi penerimaan pajak seperti pada tabel di bawah mengenai jumlah wajib pajak badan per kabupaten yang terdaftar di KPP Prtama Kendari tahun 2014-2016.

Tabel 1

Jumlah Wajib Pajak Badan per Kabupaten yang Terdaftar di KPP Pratama Kendari Tahun 2014-2016

\begin{tabular}{|l|c|c|c|}
\hline \multicolumn{4}{|c|}{ Kota Kendari } \\
\hline Uraian/Tahun & $\mathbf{2 0 1 4}$ & $\mathbf{2 0 1 5}$ & $\mathbf{2 0 1 6}$ \\
\hline Re Terdaftar & 5.994 & 6.246 & 6.856 \\
\hline Tingkat Kepatuhan & 7.228 & 4.256 & 4.930 \\
\hline \multicolumn{4}{|c|}{ Kab. Konawe } \\
\hline WP Terdaftar & 3.023 & 3.156 & 3.828 \\
\hline Realisasi SPT & 2.022 & 1.997 & 2.459 \\
\hline Tingkat Kepatuhan & $66,89 \%$ & $63,28 \%$ & $64,24 \%$ \\
\hline \multicolumn{4}{|c|}{ Kab. Konawe Selatan } \\
\hline WP Terdaftar & 1.959 & 2.593 & 2.724 \\
\hline Realisasi SPT & 1.368 & 1.912 & 1.848 \\
\hline Tingkat Kepatuhan & $69,83 \%$ & $73,74 \%$ & $67,84 \%$ \\
\hline \multicolumn{4}{|c|}{ Kab. Konawe Utara } \\
\hline WP Terdaftar & 375 & 397 & 421 \\
\hline
\end{tabular}




\begin{tabular}{|l|c|c|c|}
\hline \multicolumn{1}{|c|}{ Uraian/Tahun } & $\mathbf{2 0 1 4}$ & $\mathbf{2 0 1 5}$ & $\mathbf{2 0 1 6}$ \\
\hline Realisasi SPT & 291 & 248 & 283 \\
\hline Tingkat Kepatuhan & $77,60 \%$ & $62,47 \%$ & $67,22 \%$ \\
\hline \multicolumn{4}{|c|}{ Total } \\
\hline WP Terdaftar & 11.351 & 12.392 & 13.829 \\
\hline Realisasi SPT & 7.909 & 8.413 & 9.520 \\
\hline Tingkat Kepatuhan & $70 \%$ & $68 \%$ & $69 \%$ \\
\hline
\end{tabular}

Sumber: KPP Pratama Kendari, 2018

Tabel tersebut menunjukkan tingkat kepatuhan wajib pajak badan yang menurun di KPP Pratama Kendari yang terdiri dari empat wilayah yaitu Kota Kendari, Konawe Selatan, Konawe dan Konawe Utara. Tarif $\mathrm{PPh}$ suatu perusahaan didasarkan pada peredaran brutonya. Apabila perusahaan memiliki peredaran bruto yang tidak melebihi $\mathrm{Rp}$ 4.800.000.000 maka dikenakan $\mathrm{PPh}$ final dengan tarif $1 \%$. Jika peredaran brutonya lebih dari Rp. 4.800.000.000 maka dikenakan tarif 25\%. Hal ini berdasarkan Peraturan Pemerintah Nomor 46 Tahun 2013. Wajib pajak badan yang terdaftar pada umumnya dikenakan tarif pajak $1 \%$ dan hanya sebagian kecil wajib pajak badan yang dikenai tarif pajak $25 \%$. Hal ini disebabkan oleh faktor penghasilan yang diperoleh oleh masing-masing entitas sebagian besar masih dibawah Rp. 4.800.000.000.

Data pada tabel di atas menunjukan bahwa tahun 2015 yaitu $68 \%$ dari tahun sebelumnya yang mengalami peningkatan. Hal ini menunjukkan tingkat kepatuhan yang masih belum efektif. Kepatuhan wajib pajak juga dipengaruhi oleh tarif pajak. Dari sistem perpajakan, aspek terendah yang dinilai kurang memotivasi wajib pajak dalam membayar pajak adalah berkenaan dengan masalah tarif. Meskipun jaring pengaman bagi wajib pajak (berupa Nomor Pokok Wajib Pajak) agar melaksanakan kewajiban perpajakannya sudah dipasang, terutama bagi usaha-usaha kecil menengah tersebut, tetapi masih tetap ditemukan usaha-usaha kecil menengah yang lepas dari jeratan pajak. Sebenarnya masih banyak wajib pajak potensial yang belum terdaftar sebagai wajib pajak aktual. Ketidaktaatan dalam membayar pajak tidak hanya terjadi pada lapisan pengusaha saja tetapi telah menjadi hal yang umum bahwa para pekerja profesional lainnya juga tidak taat untuk membayar pajak.

PT. Bank Pembangunan Daerah Sulawesi Tenggara merupakan perusahaan yang bergerak dibidang perbankan dan terdaftar sebagai salah satu wajib pajak badan di Kantor Pelayanan Pajak Pratama (KPP) Kendari. PT. Bank Pembangunan Daerah Sulawesi Tenggara melakukan pembayaran pajak yang salah satunya adalah pajak penghasilan (PPh) badan berdasarkan Undang-Undang No. 36 Tahun 2008. Pajak Penghasilan yang harus dibayar sendiri oleh wajib pajak pada setiap tahun. Oleh sebab itu, dengan adanya sistem perpajakan yang ada yaitu self assesment maka PT. Bank Pembangunan Daerah Sulawesi Tenggara melakukan perhitungan, penyetoran dan pelaporan sesuai dengan ketentuan perpajakan.

PT. Bank Pembangunan Daerah Sulawesi Tenggara menerbitkan laporan keuangan setiap tahun dan menyertakan Laba Setelah Pajak (EAT) yang artinya setiap tahun PT.

Bank Pembangunan Daerah Sulawesi Tenggara melunasi beban pajaknya sehingga menjadi salah satu pionir kepatuhan wajib pajak.

Berdasarkan uraian di atas, peneliti termotivasi untuk melakukan penelitian ini karena dalam meningkatkan penerimaan pajak diperlukan tingkat 
kepatuhan dari masing-masing wajib pajak. Mengingat kepatuhan wajib pajak merupakan faktor penting bagi peningkatan penerimaan pajak, maka perlu upaya penagihan pajak agar wajib pajak dapat mematuhi kewajibannya. Hal ini diharapkan dapat menambah dan mendorong sumber-sumber penerimaan dari sektor pajak untuk membantu kelancaran dalam hal pembangunan. Selain itu, dalam rangka meningkatkan kepatuhan perpajakan, upaya penagihan pajak sangatlah penting dilakukan dengan memperlihatkan optimalisasi jumlah wajib pajak tertagih dengan besaran pajak yang dihitung berdasarkan tarif yang berlaku sesuai undang-undang perpajakan. Untuk itu peneliti menaruh perhatiannya pada penagihan pajak terhadap penerimaan pajak dalam kondisi kepatuhan wajib pajak. Penelitian dan analisis ini dikembangkan dalam bentuk artikel yang berjudul "Analisis Struktur Tarif Pajak dalam Menilai Kepatuhan Wajib Pajak Badan".

\section{B. TELAAH PUSTAKA}

\section{B.1 Pajak}

Pasal 1 Ayat (1) Undang-undang Nomor 28 tahun 2007 mengenai Ketentuan Umum dan Tata Cara Perpajakan mendefinisikan pajak sebagai kontribusi wajib kepada negara yang terhutang oleh orang pribadi atau badan yang bersifat memaksa berdasarkan undangundang dengan tidak mendapatkan imbalan secara langsung dan digunakan untuk keperluan negara bagi sebesar-besarnya kemakmuran rakyat. Sedangkan, menurut Rochmat Soemitro dalam Awaluddin (2017), pajak adalah iuran rakyat kepada kas negara berdasarkan undang-undang (yang dapat dipaksakan) dengan tidak mendapat jasa timbal (kontra prestasi), yang langsung dapat ditunjukkan dan yang digunakan untuk membayar pengeluaran umum.

Selanjutnya, Mardiasmo (2016) menjelaskan bahwa pada umumnya dikenal dua fungsi utama pemungutan pajak yaitu:

1. Fungsi Anggaran (Budgetair)

2. Fungsi Mengatur (Regulated) Mardiasmo (2016) juga menyebutkan syarat pemungut pajak yaitu:

1. Pemungutan pajak harus adil (Syarat Keadilan)

2. Pemungutan pajak harus berdasarkan undang-undang (Syarat Yuridis)

3. Tidak mengganggu perekonomian (Syarat Ekonomis)

4. Pemungutan pajak harus efisien (Syarat Finansial)

5. Sistem pemungutan pajak harus sederhana

Selain itu, Suandy (2011) pembagian pajak dapat dilakukan berdasarkan golongan, wewenang pemungut, maupun sifatnya sebagai berikut:

1. Berdasarkan golongannya
a. Pajak langsung
b. Pajak tidak langsung

2. Berdasarkan wewenang
a. Pajak pusat/pajak negara
b. Pajak daerah

3. Berdasarkan sifat
a. Pajak subjektif
b. Pajak objektif

Untuk pemungutan pajak, Mardiasmo (2016) mengatakan dapat dilakukan berdasarkan tiga stelsel. Ketiga stelsel tersebut antara lain stelsel nyata (riel stelsel), stelsel anggapan (fictive stelsel) dan stelsel campuran. Sedangkan sistem pemungutan pajak dibedakan menjadi Official Assessment System, Self Assessment System., dan With Holding System.

\section{B.2. Wajib Pajak}

Berdasarkan pasal 1 UndangUndang Nomor 16 Tahun 2009 tentang Ketentuan Umum dan Tata Cara Perpajakan, wajib pajak adalah orang pribadi atau badan, meliputi pembayar pajak, pemotong pajak, dan pemungut pajak, yang mempunyai hak dan kewajiban perpajakan sesuai dengan ketentuan perundang-undangan perpajakan. Adapun berdasarkan UU Perpajakan Wajib Pajak tersebut terdiri dari Wajib Pajak Orang Pribadi, Wajib Pajak Badan, dan 
Wajib Pajak Bendahara sebagai pemungut dan pemotong pajak.

\section{B.3. Tarif Pajak}

Tarif pajak adalah tarif yang digunakan untuk menghitung besarnya pajak yang terhutang. Besarnya tarif pajak dapat dinyatakan dalam bentuk persentase. Menurut Mardiasmo (2016), tarif pajak terdiri dari tarif sebanding/proporsional, tarif tetap, tarif progresif, dan tarif degresif.

Peraturan Pemerintah Nomor 46 Tahun 2013 adalah peraturan yang mengatur besarnya pajak terhutang atas penghasilan Wajib Pajak dengan peredaran bruto tertentu dalam tahun pajak. Peraturan baru ini bersifat final dengan tarif $1 \%$ dari peredaran bruto. Sebelum adanya peraturan baru ini, Wajib Pajak dengan peredaran bruto kurang dari $\mathrm{Rp}$ 4.800.000.000 dalam tahun pajak menggunakan Pajak Penghasilan Pasal 25 dengan tarif $12,5 \%$ dari laba sebelum pajaknya. Tarif dan dasar Pengenaan Pajak PP No. 46 Tahun 2013 yaitu dasar pengenaan pajak yang digunakan untuk menghitung pajak penghasilan yang bersifat final adalah jumlah peredaran bruto setiap bulan. Pajak penghasilan terhutang dihitung berdasarkan tarif $1 \%$ dikalikan dengan jumlah peredaran bruto setiap bulan. Dalam hal peredaran bruto kumulatif Wajib Pajak pada suatu bulan telah melebihi jumlah Rp. 4.800.000.000 dalam suatu tahun pajak, wajib pajak tetap dikenai tarif PPh yang telah ditentukan sampai dengan akhir tahun pajak yang bersangkutan. Dalam hal peredaran bruto wajib pajak telah melebihi jumlah Rp. 4.800.000.000 pada suatu tahun pajak atas penghasilan yang diterima atau diperoleh wajib pajak pada tahun pajak berikutnya dikenai tarif pajak penghasilan berdasarkan Undang-Undang Pajak Penghasilan.

Peraturan Menteri Keuangan No. 107/PMK.011/2013 adalah peraturan yang membahas tentang tata cara perhitungan, penyetoran, dan pelaporan pajak penghasilan atas penghasilan dari usaha yang diterima atau diperoleh wajib pajak yang memiliki peredaran bruto tertentu. Beberapa pokok-pokok penting yang diatur dalam PMK No. 107/PMK.011/2013 adalah sebagai berikut:

1. Tata Cara Perhitungan

Dasar pengenaan pajak untuk menghitung PPH bersifat final 1\% adalah jumlah peredaran bruto usaha setiap bulan.

2. Tata Cara Penyetoran

Beberapa hal terkait dengan tata cara penyetoran dan pelaporan $\mathrm{PPh}$ bersifat final $1 \%$ sebagai berikut:

a. Wajib pajak yang hanya menerima atau memperoleh penghasilan yang dikenai $\mathrm{PPh}$ bersifat final tidak diwajibkan melakukan pembayaran angsuran pajak sebagaimana diatur dalam pasal $25 \mathrm{UU}$ $\mathrm{PPh}$, yaitu angsuran $\mathrm{PPh}$ setiap bulan yang dibayar sendiri oleh wajib pajak. Apabila wajib pajak selain memperoleh penghasilan dengan PPh bersifat final 1\% juga menerima atau memperoleh penghasilan yang dikenai $\mathrm{PPh}$ berdasarkan tarif umum $\mathrm{PPh}$, atas penghasilan yang dikenai $\mathrm{PPh}$ berdasarkan tarif umum tersebut wajib dibayar tersebut wajib dibayar angsuran pajak sesuai ketentuan PPh Pasal 25 UU $\mathrm{PPh}$.

b. Penyetoran pajak dilakukan melalui kantor pos atau bank yang ditunjuk oleh Menteri Keuangan dengan menggunakan Surat Setoran Pajak (SSP) atau sarana administrasi lain yang dipersamakan dengan Surat Setoran Pajak yang telah mendapat validasi dengan Nomor Transaksi Penerimaan Negara (NTPN) paling lambat tanggal 15 bulan berikutnya setelah masa pajak berakhir.

c. Pelaporan dilakukan dengan menyampaikan surat pemberitahuan (SPT) masa pajak penghasilan paling lambat 20 hari setelah masa pajak berakhir. 
d. Atas penghasilan dari usaha yang diterima atau diperoleh Wajib Pajak yang memiliki peredaran bruto tertentu, yang dipotong dan/atau dipungut pihak lain diatur sebagai berikut:

i. Atas pemungutan $\mathrm{PPh}$ Pasal 22 oleh bendaharawan pemerintah dengan menggunakan SSP yang telah diisi atas nama rekanan dapat diajukan permohonan

pemindahbukuan ke setoran PPh Pasal 4 ayat (2) sesuai dengan ketentuan mengenai tata cara pembeyaran pajak melalui pemindahbukuan, dapat diajukan permohonan pengembalian pajak yang seharusnya tidak terhutang sesuai dengan ketentuan mengenai tata cara pengembalian atas kelebihan pembayaran pajak yang seharusnya tidak terhutang, atau dikreditkan terhadap pajak penghasilan yang terhutang untuk tahun pajak yang bersangkutan.

ii. Atas pemotongan dan/atau pemungutan pajak penghasilan oleh pihak lain dengan bukti pemotongan dan/atau pemungutan, termasuk pemungutan $\mathrm{PPh}$ Pasal 22 atas impor dapat diajukan permohonan pengembalian pajak yang seharusnya tidak terhutang sesuai dengan ketentuan mengenai tata cara pengembalian atas kelebihan pembayaran pajak yang seharusnya tidak terhutang atau dikreditkan terhadap pajak penghasilan yang terhutang tahun pajak yang bersangkutan.

e. Atas penghasilan dari usaha yang dikenai $\mathrm{PPh}$ bersifat final 1\% dilaporkan dalam Surat Pemberitahuan Tahunan $\mathrm{PPh}$ pada kelompok penghasilan yang dikenai pajak bersifat final, sebagai berikut:

i. Formulir 1770-III atau Lampiran III bagian A nomor 16 ("Penghasilan Lain yang Dikenakan Pajak Final dan/atau bersifat final") bagi wajib pajak orang pribadi.

ii. Formulir 1771-IV atau Lampiran IV bagian A nomor 14 dengan menuliskan "Penghasilan usaha Wajib Pajak memiliki peredaran bruto tertentu" bagi Wajib Pajak badan.

Tarif wajib pajak badan diIndonesia telah berubah yaitu dari tarif progresif menjadi tarif flat pada tahun 2008. Berdasarkan Tarif Pajak Penghasilan Wajib Pajak Badan pasal 17 Undang-Undang Nomor 36 Tahun 2008, maka dapat disimpulkan tarif pajak yang ada di Indonesia memilih untuk menetapkan tarif progresif, di mana semakin tinggi penghasilan seseorang setiap tahunnya, maka semakin besar pajak yang harus disetorkan kepada negara. Sistem tarif pajak progresif ini terlihat adil di mana setiap orang yang memiliki penghasilan yang lebih besar akan membayar beban pajak yang lebih besar pula. Namun, pada prakteknya sering sekali tarif pajak yang sudah ditetapkan di atas tidak terwujud pada realitas yang ada pada masyarakat.

\section{B.4. Kepatuhan Pajak}

Kepatuhan perpajakan didefinisikan sebagai suatu keadaan dimana wajib pajak memenuhi semua kewajiban perpajakan dan melaksanakan hak perpajakannya (Safri, 2003). Sedangkan, menurut Nasucha (2004), kepatuhan wajib pajak dapat diidentifikasi dari kepatuhan wajib pajak dalam mendaftarkan diri, kepatuhan untuk menyetorkan kembali Surat Pemberitahuan, kepatuhan dalam penghitungan dan pembayaran pajak terutang, dan kepatuhan dalam pembayaran tunggakan. Berdasarkan Peraturan Menteri Keuangan Nomor 74/PMK.03/2012, untuk dapat 
ditetapkan sebagai wajib pajak dengan kriteria tertentu, wajib pajak harus memenuhi persyaratan sebagai berikut:

$\begin{array}{lr}\text { 1. Tepat waktu dalam } \\ \text { menyampaikan } & \text { Surat } \\ \text { Pemberitahuan; } & \end{array}$

2. Tidak mempunyai tunggakan pajak untuk semua jenis pajak, kecuali tunggakan pajak yang telah memperoleh izin mengangsur atau menunda pembayaran pajak;

3. Laporan Keuangan diaudit oleh Akuntan Publik atau lembaga pengawasan keuangan pemerintah dengan pendapat Wajar Tanpa Pengecualian selama 3 (tiga) tahun berturutturut; dan

4. Tidak pernah dipidana karena melakukan tindak pidana di bidang perpajakan berdasarkan putusan pengadilan yang telah mempunyai kekuatan hukum tetap dalam jangka waktu 5 (lima) tahun terakhir.

\section{METODE PENELITIAN}

Objek dalam penelitian ini adalah tarif pajak badan usaha dalam menilai kepatuhan wajib pajak badan pada PT. Bank Pembangunan Daerah Sulawesi Tenggara yang terletak di Jl. Mayjen Soetoyo No. 95 Kendari, Provinsi Sulawesi Tenggara. Jenis data dalam penelitian ini dibedakan menjadi 2 , yaitu:

1. Data kualitatif adalah bahan keterangan dalam bentuk uraian kata-kata yang tidak dapat diukur dalam skala numerik. Pada penelitian ini, data kualitatif berupa pertanyaan deskriptif yang diperoleh dari hasil wawancara pada pemilik usaha.

2. Data kuantitatif adalah data yang disajikan dalam bentuk angkaangka dan tabel yang diperoleh dari penjumlahan dan pengukuran. Data kuantitatif dalam penelitian ini adalah laporan peredaran bruto tahun 2014, 2015 dan 2016.

Data penelitian ini berasal dari dua sumber, yaitu:
1. Data primer adalah data yang diperoleh langsung dari sumber asli (tanpa perantara). Data dalam penelitian ini diperoleh langsung dengan melakukan wawancara kepada pemilik usaha.

2. Data sekunder merupakan sumber data penelitian yang diperoleh dari peneliti secara tidak langsung. Data dalam penelitian ini adalah laporan peredaran bruto tahun 2014, 2015 dan 2016, dan gambaran umum usaha serta struktur organisasi usaha.

Metode pengumpulan data yang digunakan adalah:

1. Wawancara yaitu dengan melakukan tanya-jawab dengan pihak yang dianggap mengetahui informasi yang dibutuhkan. Teknik wawancara yang digunakan dalam penelitian ini adalah teknik wawancara yang mendalam dan tidak terstruktur, pedoman wawancara yang digunakan berupa garis-garis besar yang akan dipertanyakan dan dapat dikembangkan sesuai dengan kebutuhan informasi namun tetap fokus pada masalah penelitian.

2. Dokumentasi yaitu mengumpulkan data berupa dokumen-dokumen yang berupa tulisan atau catatan-catatan untuk penelitian yang diperlukan.

3. Studi kepustakaan dilakukan dengan mengumpulkan dan menganalisis sumber informasi, baik berupa buku, jurnal, artikel, ketentuan dalam UndangUndang Perpajakan yang relevan, maupun informasi lain yang diupload di internet sehubungan dengan permasalahan yang diteliti.

Lebih lanjut, metode yang digunakan dalam penelitian ini adalah metode analisis deskriptif. Metode analisis deskriptif adalah kegiatan menyimpulkan data mentah dalam jumlah yang besar sehingga hasilnya dapat ditafsirkan. Semua bentuk analisis tersebut mencoba untuk menggambarkan pola-pola yang konsisten dalam 
data, sehingga hasilnya dapat dipelajari dan ditafsirkan secara singkat dan penuh makna (Kuncoro, 2009). Adapun langkah-langkahnya yaitu:

1. Memeriksa dokumen yang berkaitan dengan pendaftaran usaha untuk mendapatkan NPWP yang dapat dilihat dalam identitas yang tercantum dalam SPT.

2. Menganalisis nilai peredaran bruto pada tahun 2014-2016.

3. Menganalisis peredaran bruto PT. Bank Pembangunan Daerah Sulawesi Tenggara pada tahun 2014-2016. Apabila tahun sebelumnya memiliki peredaran bruto yang tidak melebihi $\mathrm{Rp}$ 4.800.000.000 maka dikenakan $\mathrm{PPh}$ final dengan tarif $1 \%$. Jika peredaran brutonya lebih dari Rp 4.800.000.000 maka dikenakan tarif $25 \%$.

4. Menganalisis ketepatan jumlah, waktu penyetoran, dan pelaporan PPh pada badan usaha.

5. Data primer yang diperoleh dijadikan dasar untuk mempertegas analisis data sekunder.

\section{HASIL PENELITIAN}

\section{D.1. Analisis Dokumen Pendaftaran Usaha Wajib Pajak}

Analisis dokumen pendaftaran usaha wajib pajak digunakan untuk mengetahui gambaran atau deskripsi masing-masing objek penelitian yang terkait dengan status keterdaftaran sebagai wajib pajak. PT. Bank Pembangunan Daerah Sulawesi Tenggara sebagai salah satu perusahaan yang menjadi sampel penelitian terdaftar sebagai wajib pajak sejak tahun 1968 dengan Nomor Pokok Wajib Pajak (NPWP) 01.125.876.1812.000. Hasil analisis dokumen dan wawancara dengan karyawan PT. Bank Pembangunan Daerah yang memiliki kewenangan dalam tupoksi tersebut menunjukan bahwa perusahaan terdaftar sebagai wajib pajak sesuai dengan Nomor Pokok Wajib Pajak (NPWP) yang ada dan selalu melaporkan dan membayarkan kewajiban pajaknya setiap tahun sesuai dengan tarif yang dikenakan yang termaksud dalam SPT.

\section{D.2. Analisis Nilai Peredaran Bruto}

Pada analisis peredaran bruto objek penelitian, kinerja keuangan perusahaan akan berbeda satu dengan lainnya sesuai dengan skala usahanya. Adapun peredaran bruto perusahaan dapat dilihat pada laporan keuangan perusahanperusaan tersebut yang terangkum pada tabel berikut:

\section{Tabel 2}

Peredaran Bruto pada Tahun 2014-2016

\begin{tabular}{|l|c|c|c|}
\hline \multirow{2}{*}{ Nama perusahaan } & \multicolumn{3}{|c|}{ Peredaran Bruto } \\
\cline { 2 - 4 } & Tahun 2014 & Tahun 2015 & Tahun 2016 \\
\hline $\begin{array}{l}\text { PT Bank } \\
\text { Pembangunan } \\
\text { Daerah Sultra }\end{array}$ & Rp.159.259.575.452 & Rp.173.418.175.714 & Rp.222.234.235760 \\
\hline
\end{tabular}

Sumber: Data penelitian yang diolah, 2018

Berdasarkan tabel tersebut, maka dapat dikatakan bahwa peredaran bruto dari tahun 2014 sampai dengan tahun 2016 mengalami peningkatan. Hal ini bisa dipicu oleh faktor-faktor mikro yang terjadi selama rentang penelitian, misalnya politik, ekonomi, sosial, dan sebagainya yang tidak dimasukan dalam variabel dalam penelitian ini. Peredaran bruto PT. Bank Pembangunan Daerah pada tahun 2014 sebesar Rp. 159.259.575.452, tahun 2015 sebesar Rp. 173.418.175.714 dan tahun 2016 sebesar Rp. 222.234.235760. Hal ini berarti bahwa kinerja keuangan perusahaan terus mengalami peningkatan sehingga dapat disimpulkan bahwa kemampuan untuk melunasi segala kewajibannya dapat terpenuhi termasuk kewajiban pajak sesuai 
tarif yang dikenakan. Maka hal ini menjadi salah satu faktor pendorong terbayar dan dilaporkannya kewajiban pajak perusahaan.

\section{D.3. Analisis Tarif PPh Perusahaan}

Berdasarkan tabel di bawah ini, peredaran bruto PT. Bank Pembangunan Daerah pada tahun 2014 sebesar Rp. 159.259.575.452 tahun 2015 sebesar Rp. 173.418.175.714 dan tahun 2016 sebesar Rp. 222.234.235760. Hal ini berarti bahwa berdasarkan UndangUndang Pajak Penghasilan Nomor 36 Tahun 2008 maka $\mathrm{PPh}$ perusahaan pada tahun 2014, 2015 dan tahun 2016 dikenakan tarif $25 \%$ karena nilai peredaran

Tabel 3

Penghasilan Kena Pajak PT. Bank Pembangunan Daerah Sebelum dan Setelah Koreksi Fiskal

\begin{tabular}{|c|c|c|c|}
\hline Tahun & $\begin{array}{c}\text { Penghasilan Kena } \\
\text { Pajak Sebelum } \\
\text { Koreksi Fiskal } \\
\text { (Rp) }\end{array}$ & $\begin{array}{c}\text { Jumlah Koreksi } \\
\text { Fiskal } \\
\text { (Rp) }\end{array}$ & $\begin{array}{c}\text { Penghasilan Kena } \\
\text { Pajak Setelah Koreksi } \\
\text { Fiskal } \\
\text { (Rp) }\end{array}$ \\
\hline 1 & 2 & 3 & 3 \\
\hline $\mathbf{2 0 1 4}$ & 159.259 .575 .452 & 6.543 .737 .252 & 165.803 .312 .000 \\
\hline $\mathbf{2 0 1 5}$ & 173.418 .175 .714 & 11.521 .250 .293 & 184.767 .426 .000 \\
\hline $\mathbf{2 0 1 6}$ & 222.234 .235 .760 & 7.317 .805 .430 & 229.337 .041 .000 \\
\hline
\end{tabular}

Sumber: Data penelitian yang diolah, 2018

Tabel 4

Besaran Nominal Pajak Penghasilan

\begin{tabular}{|c|c|c|c|}
\hline \multirow[b]{2}{*}{ Tahun } & \multicolumn{3}{|c|}{ PT Bank Pembangunan Daerah Sultra } \\
\hline & $\begin{array}{c}\text { Dasar } \\
\text { Pengenaan } \\
\text { Pajak } \\
\text { (Rp) }\end{array}$ & Tarif & $\begin{array}{c}\text { Pajak } \\
\text { Terhutang } \\
\text { (Rp) }\end{array}$ \\
\hline 1 & 2 & 3 & $4(2 * 3)$ \\
\hline 2014 & 165.803 .312 .000 & $25 \%$ & 41.450 .828 .000 \\
\hline 2015 & 184.767 .426 .000 & $25 \%$ & 46.191 .856 .500 \\
\hline 2016 & 229.337 .041 .000 & $25 \%$ & 57.334 .260 .250 \\
\hline
\end{tabular}

Sumber: Data penelitian yang diolah, 2018

Tarif pajak penghasilan badan menganut tarif tunggal yaitu sebesar $28 \%$ yang berlaku pada tahun 2009 kemudian diturunkan menjadi $25 \%$ efektif berlaku untuk tahun 2010 dan seterusnya. Tarif pajak yang ada di Indonesia memilih untuk menetapkan tarif progresif di mana semakin tinggi penghasilan seseorang setiap $\begin{array}{lrr}\text { brutonya } & \text { melebihi } & \text { Rp. } \\ \text { 4.800.000.000. } & \text { Dalam } & \text { hal }\end{array}$ peredaran bruto Wajib Pajak telah melebihi jumlah Rp. 4.800.000.000 (empat miliar delapan ratus juta rupiah) pada suatu Tahun Pajak, atas penghasilan yang diterima atau diperoleh. Wajib pajak pada tahun pajak berikutnya dikenai Pajak Penghasilan berdasarkan tarif Undang-Undang Pajak Penghasilan Nomor 36 Tahun 2008. Sesuai Undang-undang No. 36 Tahun 2008 dilakukan koreksi fiskal untuk menentukan penghasilan kena pajak (PKP). Berikut penghasilan kena pajak (PKP) PT. Bank Pembangunan Daerah Sulawesi Tenggara sebelum dan setelah koreksi fiskal. 


\section{D.4. Analisis Ketepatan Jumlah, Waktu Penyetoran dan Pelaporan PPh Perusahaan}

Analisis ketepatan jumlah, waktu penyetoran, dan pelaporan PPh PT.

\section{Tabel 5}

Kepatuhan Pajak PT Bank Pembangunan Daerah Sulawesi Tenggara

\begin{tabular}{|c|c|c|c|}
\hline \multirow{2}{*}{ No } & \multirow{2}{*}{$\begin{array}{c}\text { Jenis } \\
\text { Kepatuhan }\end{array}$} & \multicolumn{2}{|c|}{$\begin{array}{c}\text { PT Bank } \\
\text { Pembangunan Daerah }\end{array}$} \\
\hline & & Patuh & $\begin{array}{l}\text { Tidak } \\
\text { Patuh }\end{array}$ \\
\hline $\mathbf{1}$ & Kepatuhan Formal : & & \\
\hline $\mathrm{a}$ & Mendaftarkan diri & $\checkmark$ & \\
\hline $\mathrm{b}$ & $\begin{array}{l}\text { Menghitung dan } \\
\text { menyetorkan pajak }\end{array}$ & $\checkmark$ & \\
\hline $\mathrm{c}$ & $\begin{array}{l}\text { Membayar tunggakan } \\
\text { pajak }\end{array}$ & $\checkmark$ & \\
\hline $\mathrm{d}$ & $\begin{array}{l}\text { Melaporkan surat } \\
\text { pemberitahuan Pajak Ke } \\
\text { KPP }\end{array}$ & $\checkmark$ & \\
\hline 2 & Kepatuhan Material : & & \\
\hline $\mathrm{a}$ & $\begin{array}{l}\text { Tepat waktu membayar } \\
\text { pajak dalam waktu } 3 \\
\text { tahun terakhir }\end{array}$ & $\checkmark$ & \\
\hline $\mathrm{b}$ & $\begin{array}{l}\text { Tidak mempunyai } \\
\text { tunggakan pajak }\end{array}$ & $\checkmark$ & \\
\hline c & $\begin{array}{l}\text { Tidak pernah dipindana } \\
\text { karena kelakukan tindak } \\
\text { pidana dibidang } \\
\text { perpajakan }\end{array}$ & $\checkmark$ & \\
\hline
\end{tabular}

Sumber: Data penelitian yang diolah, 2018

Berdasarkan hasil wawancara dengan karyawan PT. Bank Pembangunan Daerah Sulawesi Tenggara yang memiliki kewenangan dalam tupoksi tersebut dikatakan bahwa perusahaan selalu melaporkan dan membayarkan kewajiban pajaknya setiap tahun. Dengan peredaran bruto yang tinggi maka perusahaan dapat melunasi segala kewajibannya. Tingkat peredaran bruto yang stabil memiliki keuntungan bagi perusahaan, yaitu mengamankan posisi kinerja keuangan yang baik. Hal ini juga dapat dibuktikan bahwa rata-rata perusahaan yang melakukan pelaporan dan pembayaran pajak tepat waktu dan jumlah adalah perusahaan yang memiliki kinerja keuangan atau perederan bruto yang baik dan stabil setiap tahunnya.
Bank Pembangunan Daerah Sulawesi Tenggara dapat dilihat pada tabel berikut:

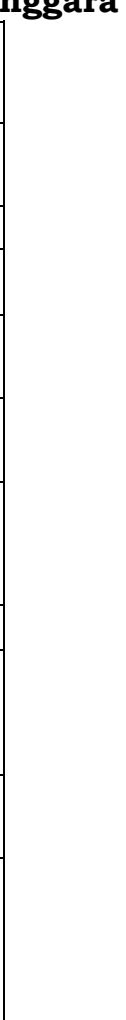

\section{E. PENUTUP}

\begin{abstract}
Berdasarkan hasil penelitian, dapat dikemukakan beberapa kesimpulan penelitian ini yaitu perusahaan yang menjadi wajib pajak harus memiliki bukti pendaftaran sebagai wajib pajak dalam bentuk Nomor Pokok Wajib Pajak (NPWP). PT. Bank Pembangunan Daerah Sulawesi Tnggara telah melakukan pendaftaran sebagai wajib pajak dan memiliki Nomor Pokok Wajib Pajak (NPWP).

Pembebanan tarif pajak perusahaan didasarkan pada peredaran bruto entitas tersebut. PT. Bank Pembangunan Daerah Sulawesi Tenggara dikenakan tarif $\mathrm{PPh}$ 25\% karena nilai peredaran brutonya melebihi Rp. 4.800.000.000. Pelaporan dan pembayaran kewajiban pajak perusahaan dilakukan berdasarkan nominal yang tertera di SPT. PT
\end{abstract}


Bank Pembangunan Daerah Sulawesi Tenggara melaporkan dan membayarkan kewajiban pajak tepat waktu dan tepat jumlah sesuai dengan tarif pajak dan waktu yang tertera dalam SPT.

Berdasarkan pada hasil temuan dan kesimpulan penelitian ini, dapat dikemukakan saran-saran yaitu diharapkan perusahaan lainnya yang terdaftar di Kantor Pelayanan Pajak Pratama Kendari untuk meningkatkan tingkat kepatuhannya dalam membayar pajak, sehingga kewajiban pajak akan selalu dibayarkan dan dilaporkan yang akan berdampak pada peningkatan penerimaan pajak. Untuk peneliti selanjutnya yaitu menambah objek penelitian agar hasil penelitian lebih berkembang dari penelitian sebelumnya.

\section{DAFTAR PUSTAKA}

Awaluddin, Ishak. 2017. Perpajakan Pembahasan Sesuai Aturan Pelaksana Perpajakan Terbaru 2017. Penerbit K-Media: Yogyakarta.

Haryuda, Agil Anggara. 2013. Pengaruh Tingkat Kesadaran, Pengetahuan dan Pemahaman Peraturan Perpajakan, Kondisi Keuangan serta Tarif Pajak terhadap Kepatuhan Membayar Pajak Wajib Pajak Badan. Jurnal. Online.

Kristanty, Nova. 2014. Pengaruh Pengetahuan Wajib Pajak, Tarif Pajak, dan Penyuluhan Pajak terhadap Tingkat Kepatuhan Wajib Pajak Badan di Kantor Pelayanan Pajak. Jurnal. Online

Kuncoro, Mudrajad. 2009. Mahir Menulis. Penerbit Erlangga: Jakarta.

Mardiasmo. 2016. Perpajakan, Edisi Terbaru 2016. Penerbit Andi: Yogyakarta.

Nasucha, Chaizi. 2004, Reformasi Administrasi Publik. PT Grasindo: Jakarta.

Nurmantu, Safri. 2003. Pengantar Perpajakan. Kelompok Yayasan Obor: Jakarta.
Peraturan Menteri Keuangan Nomor 74/PMK.03/2012 tentang Tata Cara Penetapan dan Pencabutan Penetapan Wajib Pajak dengan Kriteria Tertentu dalam rangka Pengembalian Pendahuluan Kelebihan Pembayaran Pajak.

Peraturan Menteri Keuangan Nomor 107/PMK.011/2013 Tentang Tata Cara Perhitungan, Penyetoran dan Pelaporan Pajak Penghasilan atas Penghasilan dari Usaha yang Diterima atau Diperoleh Wajib Pajak yang Memiliki Peredaran Bruto Tertentu.

Peraturan Pemerintah Nomor 46 Tahun 2013 Tentang Pajak Penghasilan dari Usaha yang Diterima Atau Diperoleh Wajib Pajak yang Memiliki Peredaran Bruto Tertentu. Direktorat Jenderal Pajak Kementerian Keuangan.

Pris, Andarini. 2010. Dampak Dimensi Keadilan Pajak terhadap Tingkat Kepatuhan Wajib Pajak Badan. Skripsi.

Rahayu, Siti Kurnia. 2017. Perpajakan (Konsep dan Aspek Formal). Penerbit Reakayasa Sains: Bandung.

Resmi, Siti. 2016. Perpajakan Teori dan Kasus, Edisi 9, Buku 1. Penerbit Salemba Empat: Jakarta.

Suandy, Erly. 2011. Hukum Pajak, Edisi 5. Penerbit Salemba Empat: Jakarta.

Sutarno, Dwi Nugroho. 2017. Analisis Pemberian Natura dan Kenikmatan Pada Karyawan dalam Meminimalkan Beban Pajak. Skripsi. Fakultas Ekonomi dan Bisnis. Universitas Halu Oleo.

Undang-Undang Republik Indonesia Nomor 36 Tahun 2008 tentang Perubahan Keempat UU No 7 Tahun 1983 tentang Pajak Penghasilan. Direktorat Jenderal Pajak Kementerian Keuangan.

Undang-Undang Nomor 16 Tahun 2009 tentang Ketentuan Umum dan Tata Cara Perpajakan. 